\title{
PENENTUAN ABNORMALITAS PERGERAKAN SPERMATOZOA MANUSIA BERBASIS REGRESI LINIER
}

\author{
Nama : Moch. Hatta \\ NRP : 2210205003 \\ Pembimbing : Dr. I Ketut Eddy Purnama, ST., MT. \\ Co-Pembimbing : Dr. Adhi Dharma Wibawa, ST., MT.
}

\begin{abstract}
ABSTRAK
Salah satu faktor penentu kualitas sperma adalah motilitas spermatozoa. Motilitas spermatozoa dapat dilakukan melalui uji mikroskopis sperma. Penentuan motilitas spermatozoa secara konvensional bergantung pada keberadaan ahli di mana penilaiannya bersifat subjektif. Computer-Assisted Sperm Analysis (CASA) sangat membantu memecahkan masalah ini. Umumnya CASA dan para peneliti di bidang ini menggunakan phase contrast microscope untuk mendapatkan image dengan kontras yang lebih tinggi. Namun dalam penelitian ini penentuan posisi dan gerakan spermatozoa pada video dilakukan menggunakan rekaman video yang berasal dari bright field microscope yang berkontras rendah dengan berbagai kekurangan lainnya. Dengan kombinasi beberapa tahapan yaitu mean filter background substraction, pengaturan kontras dengan berpatokan pada Otsu threshold, proses filtering menggunakan mathematical morphology untuk menetukan posisi dari objek serta penghitungan regresi linier dan nilai root mean square $(R M S)$.

Dari hasil percobaan yang dilakukan video data spermatozoa manusia, ternyata metode di atas didapat posisi pergerakan spermatozoa hasil penjejakan dikenali bentuk lintasannya berdasarkan rata-rata jarak posisinya terhadap garis regresi linier, dengan threshold $R M S$ sebesar 10 terdapat 10 spermatozoa progresif dan 4 spermatozoa non progresif. Metode yang digunakan berhasil menentukan 14 spermatozoa manusia, terdapat $71 \%$ progresif dan $29 \%$ non progresif. Menurut WHO laboratory manual for the examination and processing of human semen tahun 2010 dengan nilai $71 \%$ progresif berarti pergerakan sperma normal.
\end{abstract}

Kata kunci : spermatozoa, regresi linier, root mean square, background substraction, mathematical morphology 
Halaman ini sengaja dikosongkan 


\section{BAB 1 \\ PENDAHULUAN}

\subsection{Latar Belakang}

Pemeriksaan sperma merupakan salah satu elemen penting dalam penilaian fertilitas atau infertilitas. Pemeriksaan sperma ini bukan hanya diperuntukkan bagi pria yang dianggap mengalami infertilitas saja, tapi beberapa kasus pasca operasi yang melibatkan organ reproduksi pria, misalnya pengangkatan salah satu testis pada kasus kanker testis.

Tes infertilitas yang paling sering digunakan adalah Spermiogram (Tamboli dkk, 2003) menurut World Health Organization (WHO) prosedur test ini memiliki dua tahap:

1. Pengujian makroskopik yaitu analisis terhadap beberapa karakteristik fisik dari semen yaitu bau, kekentalan, dan $p H$.

2. Pengujian mikroskopik yaitu analisis beberapa parameter spermatozoa yaitu : konsentrasi (kepadatan), motilitas, dan morfologi (struktur dan bentuk).

Adapun parameter untuk sperma normal adalah:

1. Berdasarkan $p H$ : semen harus bersifat agak basa 7,0 hingga 8,5.

2. Berdasarkan viskositas: semen harus mudah dituang.

3. Berdasarkan volume $2 \mathrm{~s} / \mathrm{d} 5 \mathrm{~cm}^{3}$.

4. Cacah spermatozoa (sperm count). Angka yang normal untuk ini adalah 200 juta/ $\mathrm{cm}^{3}$.

5. Kelincahan gerak (motilitas), uji ini menyatakan tingkat aktivitas sperma. Jika spermatozoa tidak bergerak, mereka tidak dapat sampai ke telur.

6. Morfologi, ini memberi informasi tentang bentuk spermatozoa.

Umumnya berbagai parameter tersebut di atas ditentukan secara subjektif oleh seorang ahli karena ketiadaan peralatan standar untuk menguji terkecuali $p H$ dan volume. Parameter kelincahan (motilitas), cacah spermatozoa dan morfologi bergantung pada pendapat tenaga ahli yang dipengaruhi oleh keadaan tenaga ahli tersebut saat melakukan pengamatan, pengalaman tenaga ahli, dan kualitas alat yang dipakai, Untuk itu dibutuhkan prosedur standar yang dapat membantu 
kinerja para ahli, salah satunya adalah menggunakan CASA (Computer-Assisted Sperm Analysis).

Sistem CASA melibatkan komponen yang presisi misalnya phase contrast microscope, di mana komponen tersebut cukup langka dan susah mendapatkannya. Sedangkan yang paling mudah diperoleh adalah bright field tetapi yang paling sulit (karena kontras yang sangat lemah. Maka penggunaan mikroskop jenis ini, dari jajaran harganya yang paling murah, memiliki tantangan untuk digunakan yang tentunya memiliki konsekuensi pada kompleksitas lebih tinggi dari segi image processing.

Maka dibutuhkan suatu sistem yang bisa mentoleransi penggunaan mikroskop yang berkualitas rendah, dengan hasil akhir yang bisa diterima. Sebagai perbandingan pada Gambar 1.1 diperlihatkan image cairan semen diambil dengan tiga jenis mikroskop, pada Gambar 1.1(a) adalah image spermatozoa yang dihasilkan dari bright field microscope, mikroskop jenis ini memiliki kualitas kontras yang rendah. (b) adalah image spermatozoa yang berasal dari phase contrast microscope yang merupakan standard CASA dengan kualitas yang tinggi. Sedangkan (c) adalah image yang diambil menggunakan differential interference contrast, yang memiliki kualitas kontras menengah.

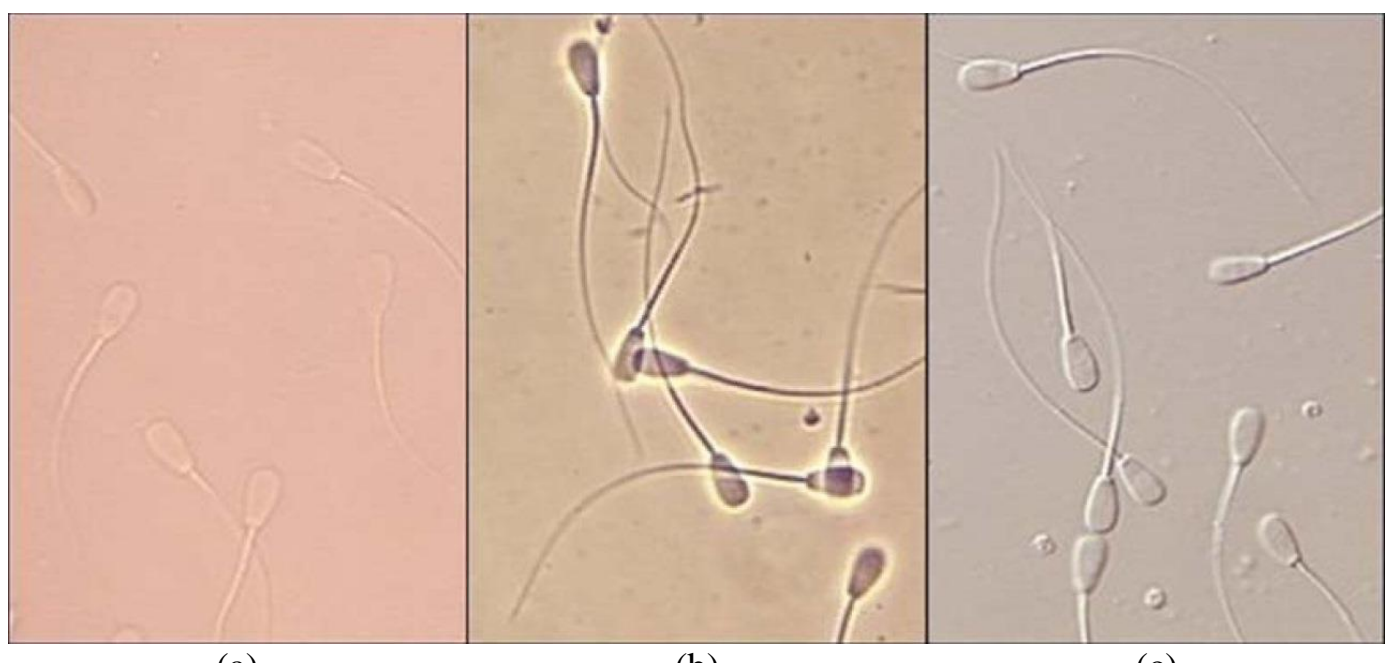

(a)

(b)

(c)

Gambar 1.1. Perbandingan image cairan semen diambil dengan tiga jenis mikroskop: (a) bright field, (b) phase contrast, dan (c) differential interference contrast. (Melissa Rouge, 2003, http://www.vivo.colostate.edu/hbooks/ pathphys/reprod/semeneval/motility.html) 
Dalam pengoperasian di lapangan kualitas image biasanya diperburuk dengan adanya noda pada lensa, variasi brightness yang tidak menentu, homogenitas brightness yang tidak merata di seluruh area, hingga gangguan death piksel pada video. Kesemuanya ini mempengaruhi terhadap seluruh frame video yang diambil dan pada kondisi lapangan yang berbeda-beda, menjadi sangat sulit dilakukan.

Identifikasi motilitas spermatozoa berdasarkan WHO laboratory manual for the examination and processing of human semen tahun 2010 terbagi menjadi: 1. motilitas progresif; dan 2. motilitas non progresif.

\subsection{Perumusan Masalah}

Dengan mengevaluasi pergerakan spermatozoa melalui mikroskop, maka deteksi motilitas sperma, yang merupakan parameter penting dalam menentukan kualitas spermatozoa dapat diketahui. Penggunaan komputer dalam bidang ini terbukti sangat membantu. Namun kebutuhan mikroskop berkualitas tinggi menyebabkan sistem ini kurang praktis digunakan, sehingga dibutuhkan suatu metode untuk bisa memungkinkan analisa gerakan spermatozoa dengan mikroskop berkontras rendah, dengan efisiensi komputasi yang tinggi.

\subsection{Batasan Masalah}

Adapun batasan masalah dalam penelitian ini adalah :

1. Deteksi motilitas hanya dilakukan terhadap spermatozoa manusia.

2. Pembesaran dari mikroskop sudah tertentu, karena sistem tidak bisa mengenali spermatozoa yang berukuran sangat kecil, misalnya kepala spermatozoa terlalu kecil.

3. Perekaman pergerakan spermatozoa menggunakan kaca objektif non cekung, sehingga gerakan spermatozoa diasumsikan sebagai gerakan 2 dimensi.

4. Penelitian dilakukan sebatas pada penjejakan gerakan spermatozoa yang difokuskan pada kemampuan mengidentifikasi pergerakan suatu spermatozoa dari frame ke frame, karena tidak adanya database video yang standar.

5. Penentuan gerakan spermatozoa secara individual dari awal kemunculannya 
hingga akhir pada sekumpulan spermatozoa, membutuhkan adanya prediktor gerakan. Dengan demikian asumsi yang dibuat bahwa spermatozoa mana pada frame $t+1$ adalah spermatozoa yang sama pada frame $t$.

\subsection{Tujuan dan Manfaat Penelitian}

Untuk mengatasi berbagai permasalahan di atas, maka dirancang sistem untuk menentukan abnormalitas pergerakan spermatozoa manusia berbasis regresi linier. Sistem ini menggunakan peralatan mikroskop bright field dan sebuah kamera Point Grey berkecepatan tinggi yang dipasangkan pada posisi okuler dan lensa objektif dengan perbesaran 40 kali, dihubungkan dengan sebuah laptop sebagai pemroses video. Sistem ini dilengkapi kemampuan perangkat lunak untuk mendeteksi gerakan sperma. Penentuan gerak spermatozoa menggunakan sistem yang dibangun bermanfaat untuk membantu tenaga ahli dalam mengetahui kualitas sperma.

\subsection{Kontribusi Penelitian}

Penelitian ini mampu memberikan kontribusi analisis spermatozoa melalui penentuan abnormalitas pergerakan spermatozoa manusia berbasis regresi linier. Penentuan ini didasarkan pada prosentase motilitas sperma progresif. Sistem pengidentifikasian tersebut dapat membantu analisis sperma dan membantu kinerja tenaga ahli. 


\section{BAB 2}

\section{TINJAUAN PUSTAKA DAN DASAR TEORI}

Identifikasi motilitas spermatozoa merupakan salah satu uji mikroskopik sperma yang digunakan untuk menentukan kualitas sperma. Kesuksesan pembuahan sel telur dipengaruhi oleh gerakan dan keaktifan spermatozoa. Pada umumnya pengamatan motilitas ini dilakukan oleh laboran dengan mengamati spermatozoa yang bergerak melalui ruang pandang mikroskop, pengamatan ini terbantu jika ada sistem pendukung terintegrasi antara mikroskop dilengkapi kamera sebagai perekam dan komputer pengolah data. Proses identifikasi motilitas spermatozoa dimulai dari pengolahan video hasil perekaman dilanjutkan dengan penjejakan spermatozoa, menghitung regresi linier lintasan sperma dan nilai root mean square $(R M S)$, serta diakhiri identifikasi spermatozoa.

\subsection{Dasar Spermatologi}

Semen merupakan hasil sekresi kelamin jantan secara normal yang diejakulasikan pada saat perkawinan. Semen terdiri dari dua bagian yaitu plasma seminalis dan spermatozoa atau sel kelamin jantan (Hardijanto dkk, 2010). Pada manusia volume semen yang diejakulasikan secara normal sekitar 2-6 ml dengan $p H$ antara 7,2-7,6. Tabel 2.1 menyajikan komposisi cairan semen untuk tiap kali ejakulasi normal pada manusia.

Tabel 2.1 Kriteria variabel cairan semen pada ejakulasi normal manusia

\section{Kriteria}

Volume
Warna
Bau
Kekentalan relatif
pH
Sel darah merah
Sel darah putih
Penggumpalan
Konsentrasi

\section{Nilai normal} 2-6 ml

Putih keabu-abuan

Seperti buah kastanye $0-5 \mathrm{~mm}$

7,2-7,6

Tidak ada $\leq 1 \mathrm{juta} / \mathrm{ml}$

Tidak ada $\geq 20 \mathrm{juta} / \mathrm{ml}$ 
lanjutan tabel 2.1

\section{Kriteria}

\section{Nilai normal}

Motilitas progresif

$>50 \%$

Motilitas maju dan cepat $\quad \geq 25 \%$

Sperma hidup $\geq 75 \%$

Sumber: WHO laboratory manual for the examination and processing of human semen, 2010

Spermatozoa atau sperm cell merupakan sel haploid ( $n$ ) yang dibentuk di dalam tubulus seminiferus dari gamet jantan melalui proses kompleks yang disebut spermatogenesis (Hayati, 2010). Spermatozoa tersusun oleh bagianbagian kepala (head), leher (connecting piece) dan ekor (tail) seperti yang ditunjukkan pada Gambar 2.1. Bagian kepala terdiri dari inti dan akrosom yang dilindungi oleh membran sel, sedangkan bagian ekor dibedakan menjadi bagian utama (middle piece), bagian tengah (principle piece) dan bagian pangkal (end piece). Sperma manusia normal memiliki panjang antara $40 \mu \mathrm{m}$ hingga $250 \mu \mathrm{m}$ (Abbiramy dkk, 2010).

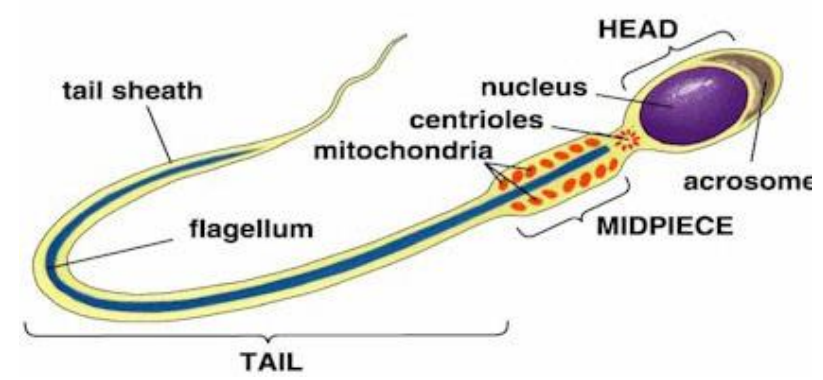

Gambar 2.1 Struktur spermatozoa manusia sebagaimana dikutip dari http://www.proceptin.com/phc/sperm-cell.php

Pada umumnya setiap penyimpangan morfologi dari struktur spermatozoa yang normal dipandang sebagai abnormal. Abnormalitas spermatozoa dapat diidentifikasikan menjadi dua, yaitu abnormalitas primer dan sekunder. Abnormalitas primer disebabkan karena kelainan spermatogenesis sejak berada di dalam tubuli seminiferi atau epitel. Sedangkan abnormalitas sekunder terjadi sesudah spermatozoa meninggalkan tubuli seminiferi, selama perjalanannya melalui epididymis, ejakulasi, manipulasi, pemanasan, pendinginan yang terlalu cepat, kontaminasi dengan air, urin atau antiseptika (Hardijanto dkk, 2010). 
Gambar 2.2 menunjukkan skema dari beberapa bentuk abnormalitas pada spermatozoa manusia.

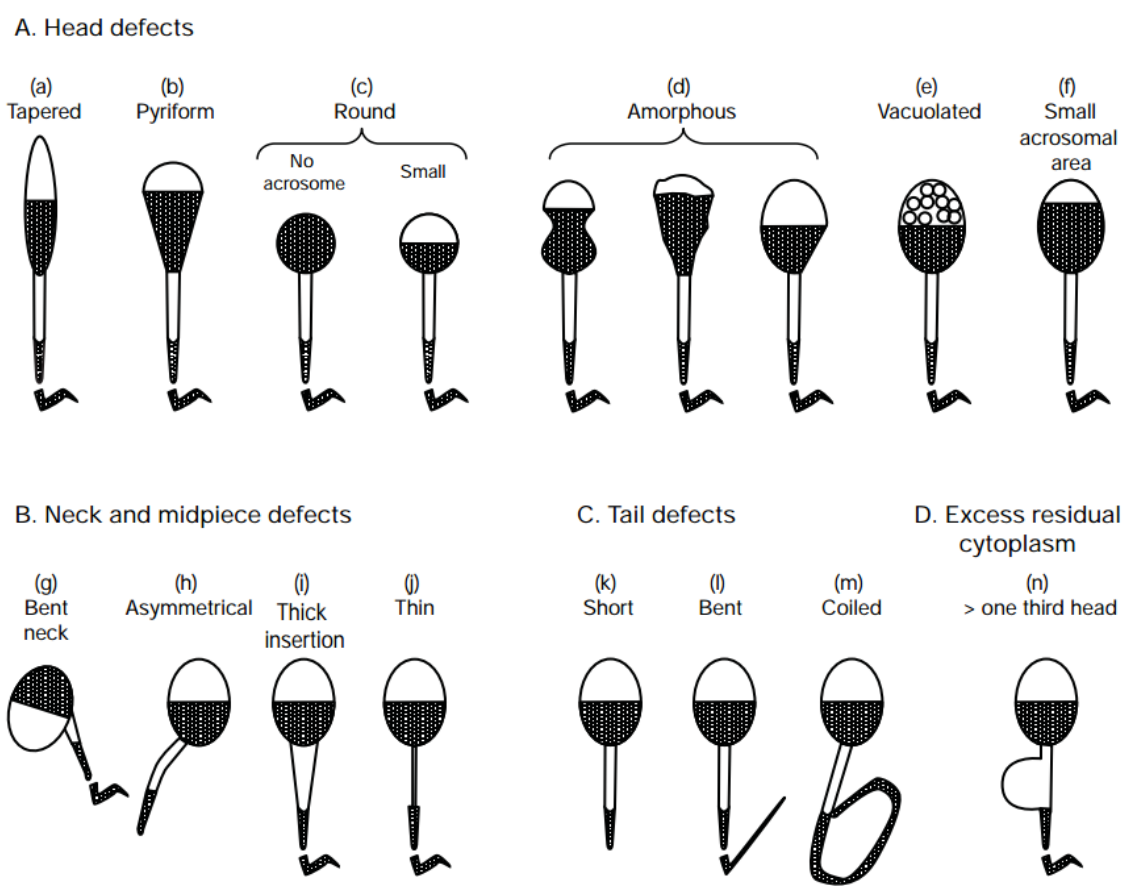

Gambar 2.2 Abnormalitas spermatozoa manusia

(Sumber: WHO laboratory manual for the examination and processing of human semen, 2010)

Abnormalitas primer meliputi kepala terlampau besar (macrocephalic), kepala terlampau kecil (microcephalic), kepala pendek melebar, pipih memanjang, piriformis, kepala rangkap, ekor berganda, bagian melipat, membengkok, membesar, bertaut abaxial pada pangkal kepala, ekor melingkar, putus, terbelah. Abnormalitas sekunder termasuk ekor yang putus, kepala tanpa ekor, bagian tengah yang melipat, adanya butiran protoplasma proksimal atau distal dan akrosom terlepas. Identifikasi tersebut tidak mutlak dan tidak mempunyai batas yang jelas, karena spermatozoa tanpa ekor dapat pula disebabkan oleh gangguan patologik, aplikasi panas dan dingin pada testis atau defisiensi makanan dan beberapa abnormalitas spermatozoa yang bersifat genetik (Hardijanto dkk, 2010).

Cairan semen yang terlalu kental mengakibatkan sel sperma sulit bergerak. Pembuahan pun jadi sulit karena sel sperma tak berhasil mencapai sel telur. Pada 
kasus normal, saat ejakulasi, cairan semen dalam bentuk yang kental akan mencair (liquifaksi) setelah 15-60 menit.

Dalam cairan semen inilah jumlah spermatozoa merupakan penentu keberhasilan memperoleh keturunan, dengan jumlah spermatozoa normal sekitar $20 \mathrm{juta} / \mathrm{ml}$. Jika ditemukan kasus spermatozoa yang kurang disebut oligozoospermia, atau bahkan jika tak ditemukan sel sperma sama sekali disebut azoospermia. Fertilisasi terjadi karena adanya pertemuan antara spermatozoa dan oosit. Keberhasilan spermatozoa dalam fertilisasi dipengaruhi juga oleh motilitasnya. Motilitas ini diperlukan pada saat spermatozoa bergerak dalam saluran reproduksi wanita dan menembus dinding zona pelusia telur dalam ampula tuba falopii. Jumlah sel sperma yang cukup, jika tak dibarengi motilitas yang normal, membuat sel sperma tak akan mencapai sel telur. Sebaliknya, kendati jumlahnya sedikit namun motilitasnya cepat, bisa mencapai sel telur.

\subsection{Mikroskop Optik}

Mikroskop Optik adalah mikroskop yang menggunakan cahaya yang bisa dilihat mata sebagai sumber cahaya. Mikroskop optik yang tergolong paling sederhana adalah bright field mikroskop. Sedangkan mikroskop optik yang khusus dibuat untuk meningkatkan kontras dan memilikii kontras yang paling tinggi adalah phase contrast microscope.

\subsubsection{Bright field microscope}

Bright field microscope bekerja dengan menyinari specimen dengan cahaya yang berasal dari bawah specimen. Objek pada specimen kemudian diperbesar oleh dua buah lensa berturut-turut yaitu objective lens dan eyepiece lens, sehingga total pembesaran yang dihasilkan adalah sebesar perkalian dari pembesaran kedua lensa tersebut. Prinsip kerja ini dapat dilihat pada Gambar 2.3. Pada Gambar 2.3 terdapat beberapa lensa tambahan dengan fungsi sebagai berikut :

(a) Tube lens, berfungsi untuk meneruskan cahaya parallel yang berasal dari objective lens, dan untuk memfokuskan image pada level diafragma dari eyepiece lens. 
(b) Pada irisan mikroskop terdapat condenser lens yang sebenarnya bukan komponen utama, berfungsi sebagai koreksi optik.

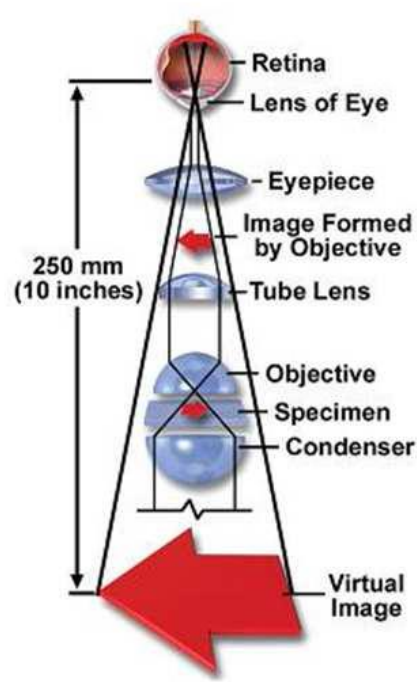

(a)

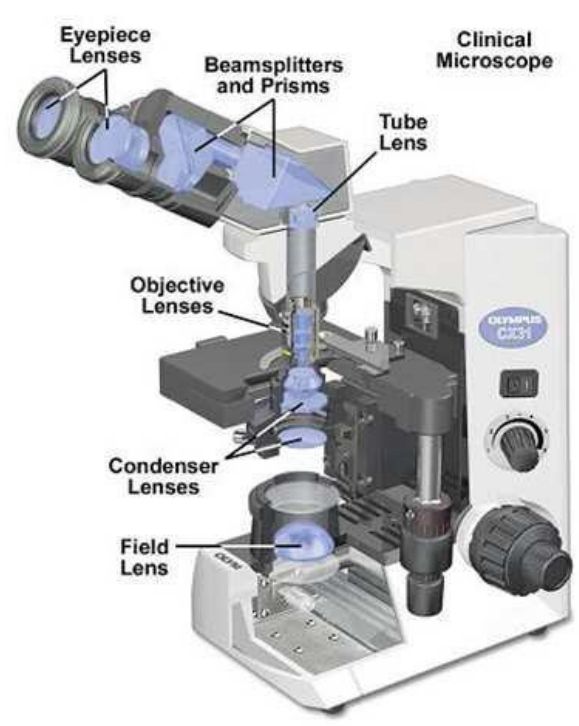

(b)

Gambar 2.3 Bright field microscope: (a) Prinsip kerja bright field microscope, (b) Irisan bright field microscope. (Mortimer Abramowitz (2003), "Microscope basic and beyond", revised edition 2003, Fellow New York Microscopical Society, New York)

Distorsi yang umum terjadi pada mikroskop adalah chromatic aberration dan spherical aberration yang cenderung menyebabkan objek yang diamati tidak bisa terfokus dengan baik. Semakin tinggi kualitas optik, koreksi atas kedua distorsi ini semakin baik sehingga image menjadi semakin jelas. Dengan bright field illumination, kekontrasan image dari bright field microscope berasal dari penyerapan cahaya dari specimen. Mikroskop jenis ini memiliki kelemahan pada kontras yang rendah sehingga umumnya dibutuhkan pewarna khusus yang dicampurkan pada specimen agar objek yang diamati terlihat dengan jelas.

\subsubsection{Phase contrast microscope}

Beberapa jenis mikroskop optik telah dibuat untuk mengatasi kelemahan bright field microscope dalam hal kontras yang rendah, di antaranya adalah differential interference contrast, Hoffman modulation contrast microscope, dan yang terbaik adalah phase contrast microscope. Prinsip phase contrast 
microscopy ditemukan oleh Frits Zernike pada 1934, dan pada tahun 1953 memenangkan penghargaan Nobel oleh karena penemuannya ini.

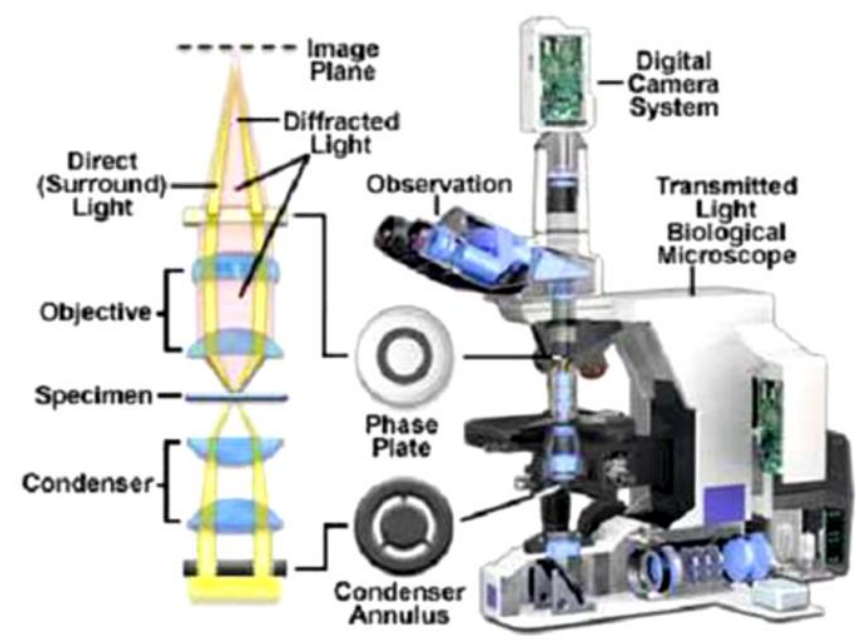

Gambar 2.4 Phase contrast microscope (http://www.microscopyu.com/articles/ phasecontrast/phasemicroscopy.html)

Prinsip kerja phase contrast microscope memanfaatkan fakta bahwa gelombang cahaya yang melalui bagian transparan dari specimen merambat lebih lambat dibandingkan dengan cahaya bebas, sehingga terjadi pergeseran fase. Pergeseran fase ini tidak terlihat oleh mata manusia. Namun perbedaan fase ini dapat ditingkatkan menjadi setengah panjang gelombang dengan menggunakan transparent phase-plate dalam mikroskop sehingga mengakibatkan terjadinya perbedaan brightness. Hal ini menyebabkan objek yang transparan menjadi jelas terlihat. Gambar 2.4 memperlihatkan komponen utama phase contrast microscope, terlihat bahwa ada penambahan transparent phase plate yang berfungsi untuk meningkatkan pergeseran fase menjadi setengah panjang gelombang.

Phase contrast microscope umum digunakan untuk mengamati objek transparan yang tidak berwarna karena memiliki kontras yang jauh lebih tinggi. Gambar 2.5 memperlihatkan perbandingan sel hidup dilihat dengan bright field microscope dan phase contrast microscope. 


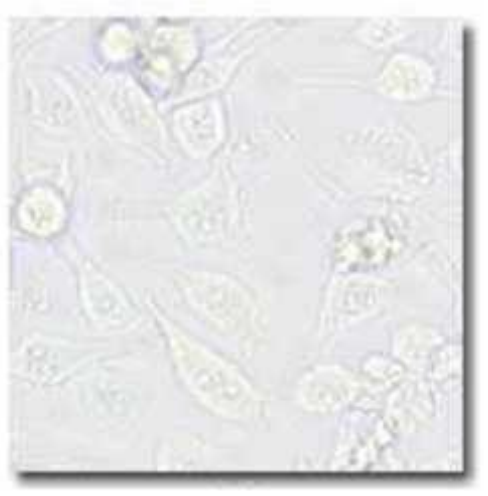

(a)

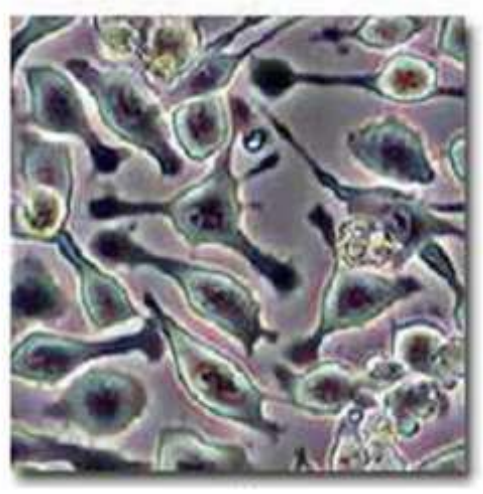

(b)

Gambar 2.5 Perbandingan kontras image sel hidup dari dua jenis mikroskop :

(a) bright field microscope, (b) phase contrast microscope (http://www.microscopyu.com/articles/phasecontrast/ phasemicroscopy.html)

\subsection{Time-Average Background Image}

Metode sederhana untuk mendapatkan background dengan cara rekonstruksi dari serangkaian gambar bergerak dapat dilakukan dengan menggunakan TABI (time-averaged background image). Metode ini sudah banyak dipakai oleh peneliti sebelumnya. Metode ini akan menghasilkan gambar background yang merupakan pendekatan dengan cara mendapatkan rata-rata nilai piksel gambar berdasarkan serangkaian frame dari serangkaian gambar.

Misalkan $\left(I_{1}, I_{2}, \ldots, I_{m}\right)$ merupakan serangkaian gambar bergerak, dipilih sejumlah frame dengan jumlah $n$ frame dari total $m$ frame dan disimbolkan dengan $\left(f_{1}, f_{2}, f_{3}, \ldots f_{n}\right) . f_{i}(a, b)$ merepresentasikan nilai piksel dari frame ke $i$ dengan $i=1,2, . . n$. Maka dapat diperoleh nilai rata-rata tiap-tiap piksel dengan rumusan pada persamaan (2.1).

$$
\bar{F}(a, b)=\frac{\sum_{i=1}^{n} f_{i}(a, b)}{n}
$$

dengan :

$\bar{F}(a, b)=$ nilai rata-rata tiap piksel

$f_{i}(a, b)=$ nilai piksel dari frame ke $i$

$(a, b)=$ koordinat titik, $a$ sebagai komponen mendatar dan $b$ sebagai komponen tegak

$n \quad=$ jumlah data

$i \quad=1,2,3, \ldots n$ 


\subsection{Mean Filter}

Hasil yang diperoleh dari proses TABI, kemudian dilanjutkan proses menghitung selisih nilai piksel antara hasil perhitungan $\bar{F}(a, b)$ dari persamaan 2.1 dengan $f_{i}(a, b)$ dengan $i=1,2, . . n$, akan didapat nilai selisih piksel $D_{i}(a, b)$ dengan rumus persamaan (2.2).

$$
D_{i}(a, b)=\left|\bar{F}(a, b)-f_{i}(a, b)\right|
$$

dengan :

$$
D_{i}(a, b)=\text { nilai selisih tiap piksel }
$$

\subsection{Citra Biner (Binary Image)}

Gambar digital adalah sebuah array angka atau intensitas citra yang tersampling (Alan Bovic, 2009). Setiap tingkat keabuan terkuantisasi satu dari himpunan berhingga yang direpresentasikan dengan bit. Dalam citra biner (binary image) hanya terdapat satu bit untuk setiap piksel yang mengimplikasikan dua kemungkinan nilai tingkat keabuan yaitu 0 dan 1 . Dua nilai ini biasanya diinterpretasikan sebagai Boolean, dimana setiap piksel bernilai true atau false. Nilai ini mengindikasikan keberadaan suatu properti citra yang terhubung dengan tingkat keabuan, citra dengan ukuran yang sama dimana ' 1 ' pada suatu koordinat mengindikasikan adanya properti pada tingkat keabuan citra pada koordinat tersebut. Sedangkan ' 0 ' pada suatu koordinat mengindikasikan tidak adanya properti pada tingkat keabuan citra pada koordinat tersebut. Properti citra ini merupakan tingkat kecerahan (brightness) intensitas tinggi atau rendah. Biasanya, ditampilkan menggunakan dua warna ekstrim yaitu hitam dan putih yang direpresentasikan dengan 0 dan 255 pada lingkungan grayscale (Alan Bovic, 2009).

Nilai gray level 0 secara umum menggunakan ' 1 ' untuk merepresentasikan 'hitam', sedangkan nilai gray level 255 secara umum menggunakan '0' untuk merepresentasikan 'putih'. Citra biner (binary image) dapat diperoleh dengan berbagai cara. Umumnya dibentuk dari tingkat keabuan citra untuk mempermudah pemrosesan. Akan tetapi, beberapa jenis sensor dapat secara langsung menghasilkan citra biner (binary image). 


\subsection{Metode Otsu}

Thresholding citra merupakan suatu teknik yang banyak digunakan untuk segmentasi, yaitu membagi citra gray level ke segmen yang sesuai untuk beberapa kelas berdasarkan nilai gray level. Pendekatan thresholding kebanyakan diusulkan untuk dua kelas, dan didasarkan pada histogram gray level dari citra. Dua dari tujuh pendekatan yang paling populer adalah metode Otsu (Otsu, 1979) dan Minimum Error Thresholding / MET (Kittler dan Illingworth, 1986). Seperti yang telah disurvey (Han Si-qi, 2002), tidak terdapat perbedaan hasil yang signifikan di antara dua metode tersebut.

Dalam penelitian ini thresholding tidak digunakan untuk segmentasi citra sebagai tujuan akhir, tetapi sebagai titik acuan dalam memaksimalkan kontras untuk pembedaan background dan foreground sebesar-besarnya. Maka pemilihan di antara kedua metode tersebut tidak berdampak penting.

Threshold membagi area ke dalam dua kelas sebagai berikut :

$$
g(a, b)= \begin{cases}0 & , f(a, b)<T \\ 1 & , f(a, b) \geq T\end{cases}
$$

dengan :

$$
\begin{array}{ll}
g(a, b) & =\text { nilai piksel citra hasil thresholding, yang berisi } 0 \text { atau } 1 \\
T & =\text { nilai threshold }
\end{array}
$$

Tujuan dari metode Otsu adalah untuk menemukan titik threshold yang membagi histogram citra gray level ke dalam dua daerah yang berbeda secara otomatis, di mana titik yang dipilih adalah sedemikian sehingga inter-class variance adalah sebesar mungkin. Tujuan tersebut dicapai dengan meminimalkan bobot within-class variance, yang sebenarnya adalah sama dengan memaksimalkan inter-class variance. 
Bobot dari within-class variance adalah :

$$
\sigma_{w}^{2}(t)=q_{1}(t) \sigma_{1}^{2}(t)+q_{2}(t) \sigma_{2}^{2}(t)
$$

dengan :

$$
\begin{aligned}
& \sigma_{w}^{2}(t)=\text { total within-class variance } \\
& \sigma_{1}^{2}(t)=\text { total within-class variance dari kelas pertama } \\
& \sigma_{2}^{2}(t)=\text { total within-class variance dari kelas kedua } \\
& q_{1}(t)=\text { class probabilities dari kelas pertama } \\
& q_{2}(t)=\text { class probabilities dari kelas kedua } \\
& t \quad=\text { nilai gray level yaitu nilai threshold }
\end{aligned}
$$

Class probablilites dari kelas pertama dan kedua adalah (di mana $i$ mewakili jumlah kemunculan piksel untuk gray-level tertentu, sedangkan $t$ adalah nilai gray level ):

$$
\begin{aligned}
& q_{1}(t)=\sum_{j=1}^{t} P(j) \\
& q_{2}(t)=\sum_{j=t+1}^{l} P(j)
\end{aligned}
$$

dengan :

$$
\begin{array}{ll}
P(j) & =\text { kemungkinan kemunculan nilai gray level tertentu } \\
j & =\text { nilai gray level } \\
t & =\text { nilai threshold } \\
l & =\text { batas akhir kelas kedua }
\end{array}
$$

Nilai rata-rata dari masing-masing kelas adalah :

$$
\begin{aligned}
& \mu_{1}(t)=\sum_{j=1}^{t} \frac{j P(j)}{q_{1}(t)} \\
& \mu_{2}(t)=\sum_{j=t+1}^{l} \frac{j P(j)}{q_{2}(t)}
\end{aligned}
$$

dengan :

$\mu_{1}(t)=$ nilai rata-rata kelas pertama $\mu_{2}(t)=$ nilai rata-rata kelas kedua 
Within-class variance dari masing-masing kelas tersebut adalah :

$$
\begin{aligned}
\sigma_{1}^{2}(t) & =\sum_{j=1}^{t}\left[j-\mu_{1}(t)\right]^{2} \frac{P(j)}{q_{1}(t)} \\
\sigma_{2}^{2}(t) & =\sum_{j=t+1}^{l}\left[1-\mu_{2}(t)\right]^{2} \frac{P(j)}{q_{2}(t)}
\end{aligned}
$$

Jika dihitung semua nilai $\sigma_{1}^{2}(t)$ dan $\sigma_{2}^{2}(t)$ pada citra gray scale maka akan diperoleh nilai within-class variance minimum. Nilai $t$ yang membuat $\sigma_{1}^{2}(t)$ dan $\sigma_{2}^{2}(t)$ menjadi minimum adalah nilai threshold yang dicari.

Namun proses komputasi dapat dihemat dengan memanfaatkan fakta bahwa total variance pada suatu image adalah selalu konstan, tidak bergantung pada nilai threshold. Sehingga untuk sebarang threshold $t$, total variance adalah jumlah dari within-class variance dan inter-class variance :

$$
\sigma^{2}=\frac{\sigma_{w}^{2}(t)}{\text { within-class variance }}+\frac{q_{1}(t)\left[1-q_{1}(t)\left[\mu_{1}(t)-\mu_{2}(t)\right]^{2}\right.}{\text { inter-class variance }=\sigma_{B}^{2}(t)}
$$

Dari persamaan di atas terlihat bahwa meminimalkan within class variance $\left(\sigma_{w}^{2}(t)\right)$ adalah sama dengan memaksimalkan interclass variance $\left(\sigma_{B}^{2}(t)\right)$. Nilai dari $\sigma_{B}^{2}(t)$ dapat dihitung secara rekursif dengan sekali jalan mulai dari nilai $t$ terendah hingga tertinggi (0 hingga 255 untuk gray scale 8 bit).

\subsection{Template matching}

Template matching adalah proses menemukan lokasi sebuah subimage, yang disebut template, di dalam image. Template biasanya mewakili fitur boundary dari objek. Template matching adalah proses membandingkan template yang ada dengan jendela dengan ukuran yang sama dalam image dan mengidentifikasi jendela yang paling mirip dengan template. Jika template dan representasi image berisi struktur binary misalnya tepi objek (contour boundary), jarak geometris adalah parameter yang biasanya dipilih untuk template matching.

Proses pencocokan boundary dikenal sebagai chamfer matching dan pertama kali diusulkan oleh Barrow et al. (1977) dalam pencocokan foto udara. Chamfer matching adalah teknik yang menggunakan jarak rata-rata antara dua 
struktur binary sebagai ukuran kesamaan. Untuk menentukan kesamaan antara template dan suatu window yang dipilih dalam image, window dan template ditumpuk sehingga saling tumpang tindih. Untuk setiap titik boundary dalam window, dicari titik paling dekat pada template dan dihitung rata- rata dari jarak antara titik-titik yang sesuai yang digunakan sebagai ukuran kesamaan.

$$
\Delta_{\text {cham }}^{(\Gamma, \varepsilon)}=\frac{1}{|\Gamma|} \sum_{\rho \in \Gamma} \min _{\rho \in \Gamma}|\rho-\varphi|
$$

dengan : $|\Gamma|$ adalah jumlah titik edge dari template $\mathrm{T}$ $\varepsilon$ adalah edge map dari image

Melalui Distance Transform, diperoleh titik-titik dengan jarak terdekat dari edge map E, sehingga komputasi menjadi lebih sederhana :

$$
\Delta_{\text {cham }}^{(\Gamma, \varepsilon)}=\frac{1}{|\Gamma|} \sum_{\rho \in \Gamma} \Phi \Gamma_{\varepsilon}(\rho)
$$

Kesamaan yang terdekat adalah posisi dimana jarak rata-rata antara template dan contour dari image adalah minimum. Semakin kecil rata-rata yang diperoleh, semakin mirip template dan window. Rata-rata nol berarti bahwa template dan window cocok dengan sempurna. Sebaliknya dengan meningkatnya rata-rata, kesamaan antara struktur antara template dan window menurun.

\subsection{Mathematical Morphology}

Morphology adalah satu cabang dari pengolahan citra yang sangat bermanfaat dalam analisis bentuk dalam citra (Indah Susilawati, 2009).

\subsubsection{Translasi}

Apabila $A$ adalah satu set piksel dalam citra biner dan $w=(c, d)$ adalah satu titik koordinat tertentu, maka $A_{w}$ adalah $A$ yang ditranslasikan (digeser) pada arah $(c, d)$. Atau dinyatakan

$$
A_{w}=\{(a, b)+(c, d) \mid(a, b) \in A\}
$$




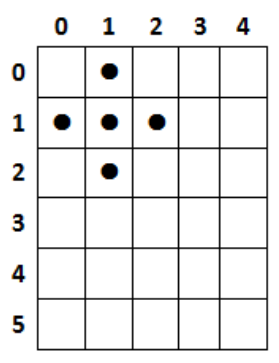

A

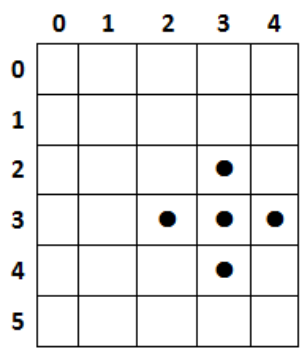

$A_{W}$

b

Gambar 2.6 Ilustrasi proses Translasi (Murinto Eko A., 2001)

Sebagai contoh adalah pada Gambar 2.6(a). A adalah set atau himpunan yang berbentuk cross dan $w=(2,2)$. Himpunan $A$ digeser ke arah sumbu $x$ dan sumbu $y$ sesuai dengan ketentuan pada $w$. Dalam hal ini digunakan koordinat matriks (bukan koordinat kartesian) sehingga titik asal seperti terlihat pada Gambar 2.6(a); $x$ berjalan vertikal dan $y$ berjalan horizontal, sehingga hasilnya tampak pada Gambar 2.6(b).

\subsubsection{Refleksi}

Jika $A$ adalah satu set piksel dalam citra biner, maka refleksi (cermin) dari $A$ dinotasikan sebagai $A^{\wedge}$ dan diperoleh dengan cara mencerminkan himpunan $A$ terhadap titik asal (origin).

$$
A^{\wedge}=\{(-a,-b) \mid(a, b) \in A\}
$$

Pada Gambar 2.7 diperlihatkan contoh cermin dari himpunan lingkaran-lingkaran berwarna putih, lingkaran-lingkaran cerminnya dinyatakan dengan lingkaran berwarna hitam. Origin atau titik asal ditentukan oleh koordinat $(0,0)$.

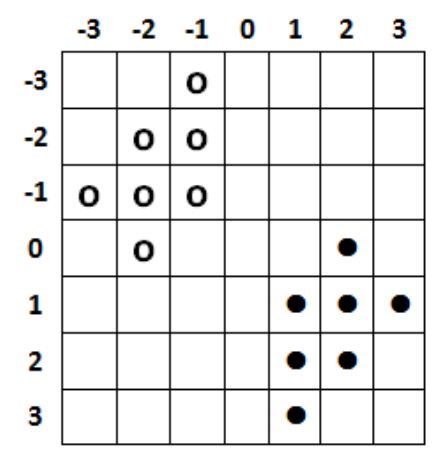

Gambar 2.7 Ilustrasi proses Refleksi (Indah Susilawati, 2009) 


\subsubsection{Dilasi (Dilation)}

Merupakan operasi dasar dalam morphology. Misalkan $A$ dan $B$ adalah himpunan-himpunan piksel. Dilasi $A$ oleh $B$ dinotasikan dengan $A \oplus B$ dan didefinisikan sebagai berikut

$$
A \oplus B=\bigcup_{e \in B} A_{e}
$$

Ini berarti bahwa untuk setiap titik $e \in B$, maka dilakukan translasi atau penggeseran dan kemudian menggabungkan seluruh hasilnya (union). Atau secara matematis dituliskan sebagai

$$
A \oplus B=\{(a, b)+(u, v) \mid(a, b) \in A,(u, v) \in B\}
$$

Dilasi mempunyai hukum komutatif, yaitu

$$
A \oplus B=B \oplus A
$$
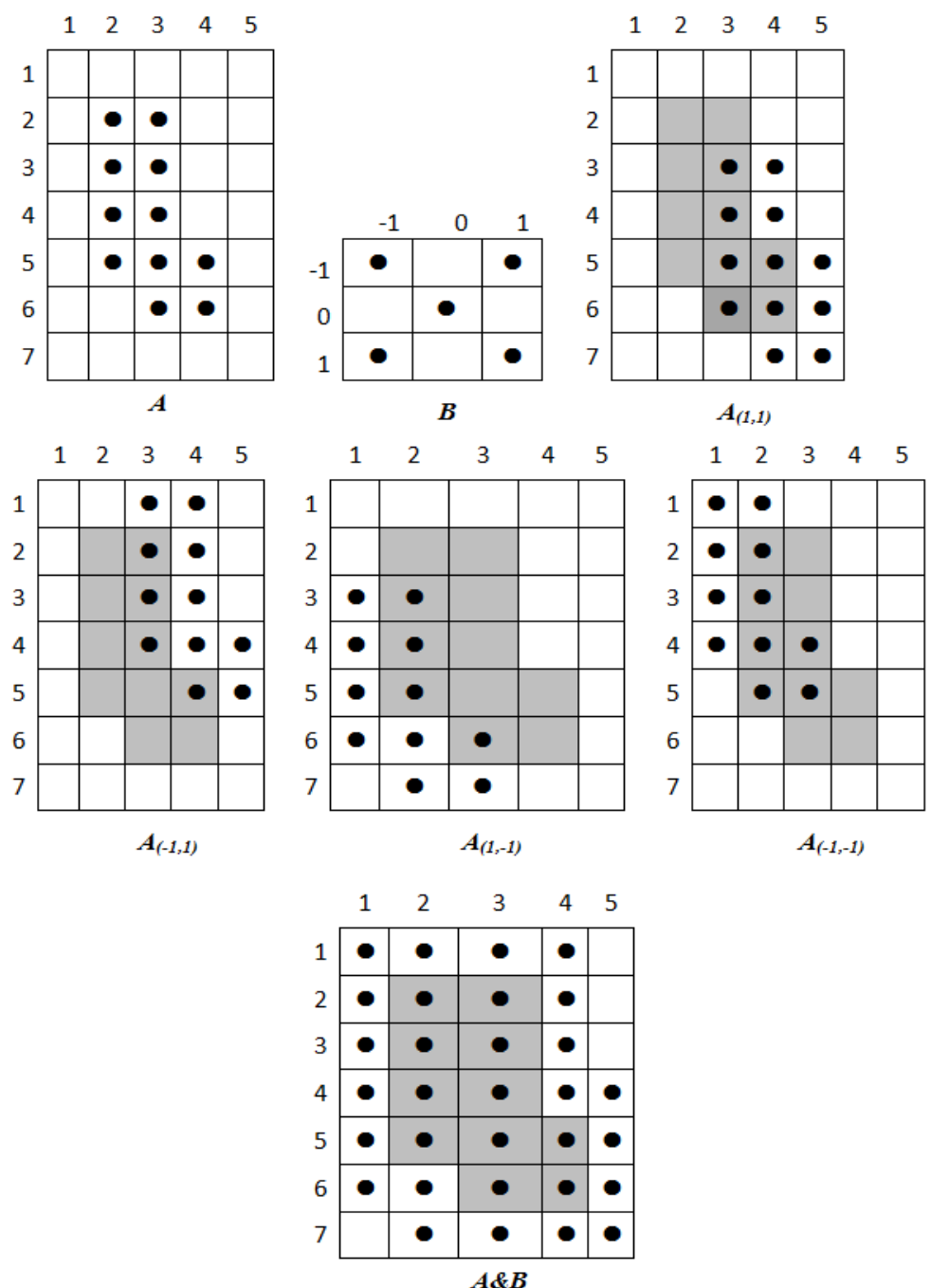

Gambar 2.8 Ilustrasi proses Dilasi (Indah Susilawati, 2009) 
Untuk dilasi maka pada umumnya diasumsikan bahwa $A$ adalah citra yang akan diolah dan $B$ adalah suatu himpunan piksel. Himpunan piksel $B$ sering disebut structuring element atau kernel.
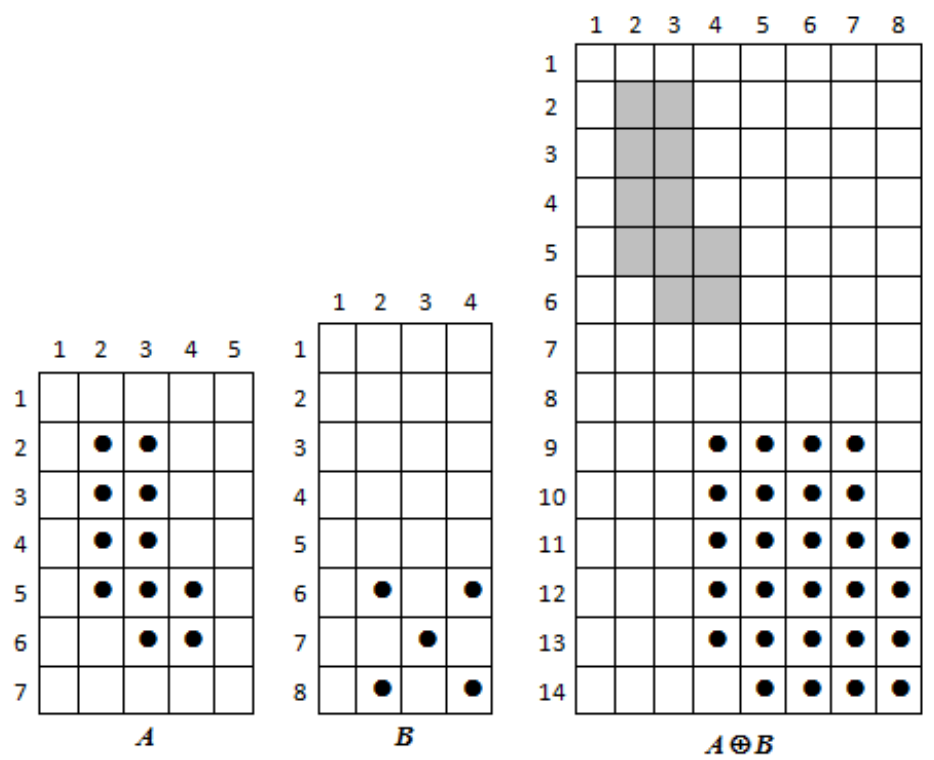

Gambar 2.9 Ilustrasi proses Dilasi (Indah Susilawati, 2009)

\subsubsection{Erosi (Erosion)}

Jika dketahui himpunan $A$ dan $B$, maka erosi $A$ oleh $B$ (dinotasikan $A \Theta B$ ) didefinisikan sebagai

$$
A \Theta B=\left\{\omega \mid B_{\omega} \subseteq A\right\}
$$

Dengan kata lain, erosi $A$ oleh $B$ terdiri atas semua titik $\omega=(m, n)$ dimana $B_{\omega}$ ada di dalam himpunan $A$. Untuk melakukan erosi, $B$ digeser-geser dalam $A$ dan dicari dimana saja $B$ bebar-benar ada di dalam $A$. Untuk kondisi-kondidi yang memenuhi syarat tersebut maka tandailah titik $(0,0)$ yang bersesuaian dengan $B$. Titik-titik ini yang merupakan hasil erosi $A$ oleh $B$. Pada Gambar 2.10 ditunjukkan erosi $A$ oleh $B$. 

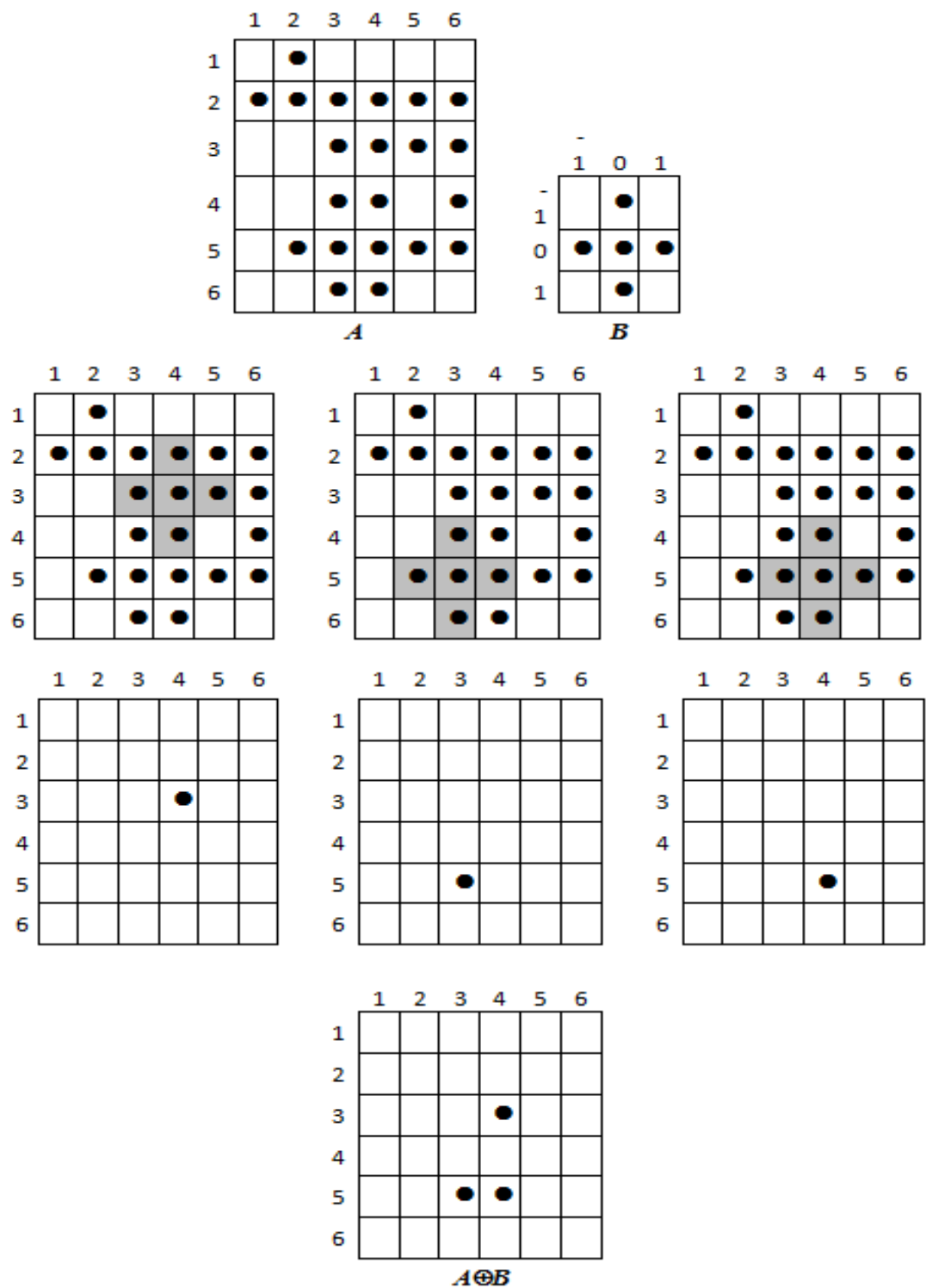

Gambar 2.10 Ilustrasi proses Erosi $A$ oleh $B$ (Indah Susilawati, 2009)

Sebagaimana pada dilasi, maka pada operasi erosi umumnya $A$ diasumsikan sebagai citra yang akan diproses dan $B$ adalah satu set (himpunan) piksel yang juga disebut structuring element atau kernel. Erosi juga sering dihubungkan dengan Minkowski subtraction yang didefinisikan sebagai

$$
A-B=\bigcap_{e \in B} A_{e}
$$




\subsubsection{Deteksi Bidang Batas (Boundary Detection)}

Salah satu aplikasi operasi erosi dan dilasi adalah untuk deteksi bidang batas suatu objek dalam citra. Jika $A$ adalah suatu citra dan $B$ adalah suatu structuring element yang kecil yang terdiri atas titik yang diletakkan secara simetris terhadap origin, maka dapat didefinisikan bidang batas $A$ dengan beberapa metode :
(i) $A-(A \Theta B)$ "internal boundary"
(ii) $(A \oplus B)-A$ "external boundary"
(iii) $(A \oplus B)-(A \Theta B)$
"morphological gradient"

\subsubsection{Opening}

Merupakan operasi morphology yang dapat dikategorikan sebagai operasi level kedua dengan arti bahwa opening dan closing dibangun berdasarkan operasi dilasi dan erosi.

Misalkan terdapat citra $A$ dan structuring element $B$, maka opening $A$ oleh $B$ dinyatakan dengan notasi $A \circ B$ dan didefinisikan sebagai berikut :

$$
A \circ B=(A \Theta B) \oplus B
$$

Sehingga operasi opening merupakan sebuah operasi yang terdiri atas operasi erosi diikuti oleh operasi dilasi. Definisi ekivalennya dapat dinyatakan sebagai berikut :

$$
A \circ B=\cup\left\{B_{\omega}: B_{\omega} \subseteq A\right\}
$$

Yang berarti bahwa $A \circ B$ adalah gabungan (union) dari seluruh pergeseran $B$ yang benar-benar tercakup (fit) dalam $A$. Hal ini berbeda dengan operasi erosi dimana erosi hanya terdiri atas titik $(0,0)$ dari $B$ sedangkan pada operasi opening maka terdiri atas semua titik pada $B$ seperti terlihat pada Gambar 2.11 . 

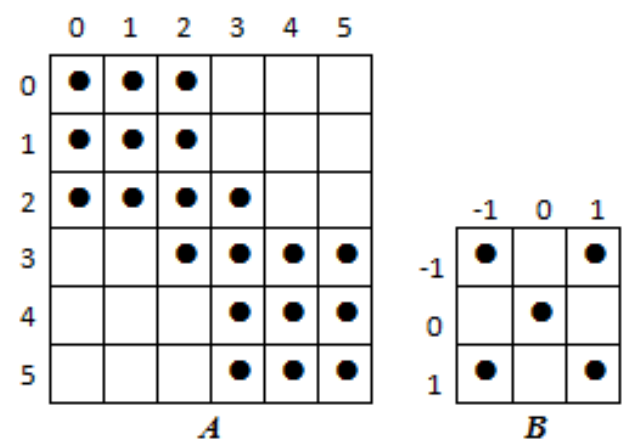

Gambar 2.11. ilustrasi himpunan piksel A dan B (Indah Susilawati, 2009)

Pada Gambar 2.12 ditampilkan ilustrasi hasil erosi dan hasil opening citra $A$ oleh $B$. Operasi opening cenderung akan memperhalus objek pada citra, memutus sambungan yang sempit (break narrow joins), dan menghilangkan efek pelebaran pada objek (remove protrusions).
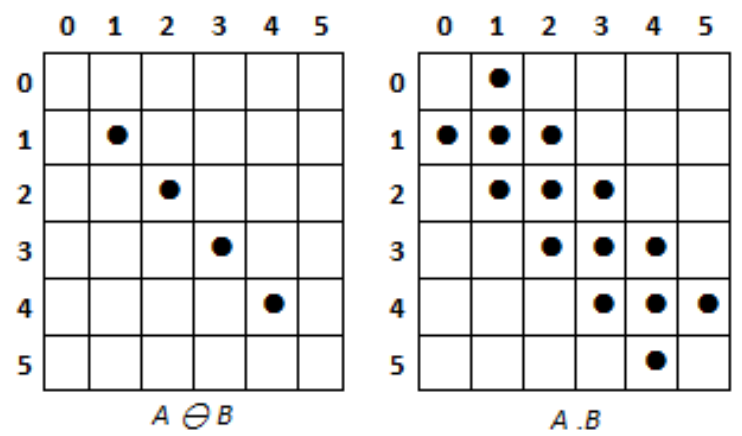

Gambar 2.12 Hasil erosi dan hasil opening citra $A$ oleh $B$ (Indah Susilawati, 2009)

\subsubsection{Closing}

Closing didefinisikan sebagai operasi dilasi yang dilanjutkan dengan operasi erosi, dinotasikan sebagai $A \cdot B$, sehingga dapat dinyatakan

$$
A \cdot B=(A \oplus B) \Theta B
$$

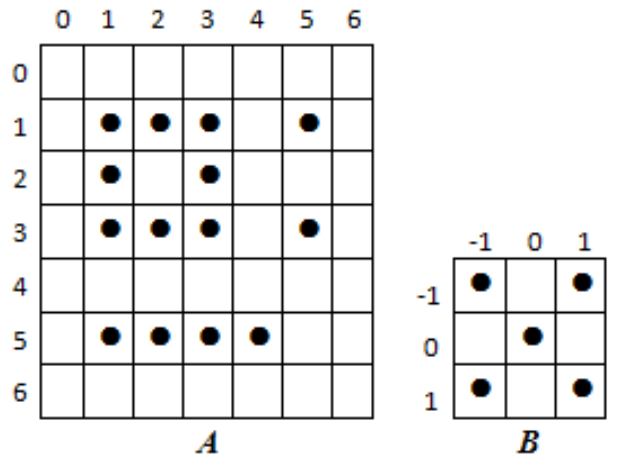

Gambar 2.13 Himpunan piksel $A$ dan $B$ (Indah Susilawati, 2009) 
Operasi closing juga cenderung akan memperhalus objek pada citra, namun dengan cara menyambung pecahan-pecahan (fuses narrow breaks and thin gulf) dan menghilangkan lubang-lubang kecil pada objek.

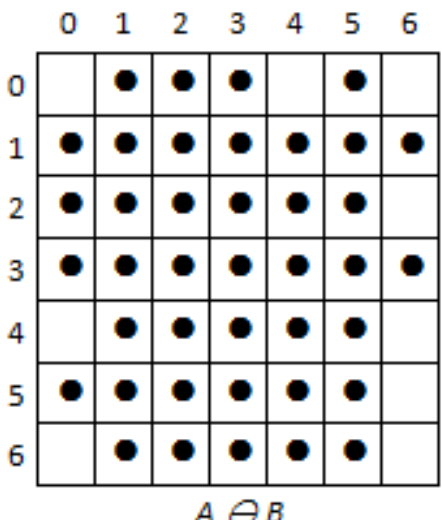

$A \ominus B$

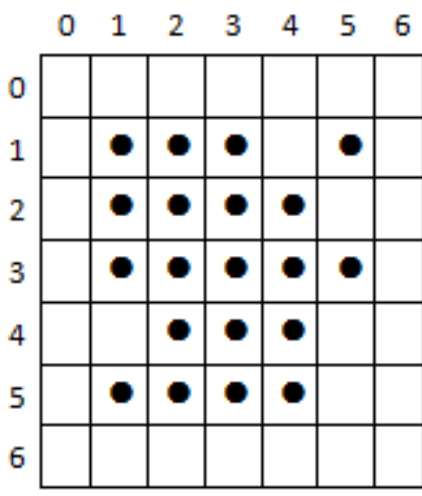

A.B

Gambar 2.14 Hasil proses Closing (Indah Susilawati, 2009)

\subsubsection{Morphology Filtering}

Apabila terdapat citra biner A yang terkena derau impuls - piksel yang seharusnya hitam menjadi putih dan sebaliknya. Maka $A \Theta B$ akan menghilangkan piksel hitam tunggal namun akan memperbesar lubang-lubang yang ada. Untuk menghilangkan lubang dapat dilakukan dilasi dua kali secara berurutan.

$$
((A \Theta B) \oplus B) \oplus B
$$

Dilasi yang pertama akan mengembalikan lubang-lubang ke ukuran semula dan operasi dilasi yang kedua akan menghilangkan lubang-lubang tersebut. Namun hal ini juga akan memperbesar objek pada citra. Untuk mengembalikan objek ke ukuran semula maka dapat dilakukan erosi, sehingga operasi secara keseluruhan dapat dinyatakan sebagai berikut.

$$
(((A \Theta B) \oplus B) \oplus B) \Theta B
$$

Operasi tersebut juga dapat dinyatakan sebagai berikut

$$
(A \circ B) \cdot B
$$

Operasi tersebut disebut morphology filtering (Indah Susilawati, 2009). 


\subsection{Segmentasi}

Dalam visi komputer, segmentasi adalah proses mempartisi citra digital menjadi beberapa segmen. Tujuan dari segmentasi adalah untuk menyederhanakan dan/atau mengubah penyajian gambar ke sesuatu yang lebih bermakna dan lebih mudah untuk menganalisis. Gambar segmentasi biasanya digunakan untuk menemukan objek dan batas-batas (garis, kurva, dll) dalam gambar. Lebih tepatnya, segmentasi citra adalah proses untuk menempatkan label untuk setiap piksel dalam sebuah gambar sehingga piksel dengan kumpulan label yang sama karakteristik visual tertentu.

Hasil segmentasi citra adalah seperangkat segmen yang secara kolektif mencakup seluruh gambar, atau satu set kontur diekstrak dari citra (lihat deteksi tepi). Setiap piksel dalam suatu wilayah mirip dengan memperhatikan beberapa karakteristik properti atau dihitung, seperti warna, intensitas, atau tekstur. Daerah yang berdekatan sangat berbeda sehubungan dengan karakteristik yang sama (Linda, 2001).

Segmentasi citra pada umumnya berdasar pada sifat discontinuity atau similarity dari intensitas piksel. Pendekatan discontinuity adalah mempartisi citra bila terdapat perubahan intensitas secara tiba-tiba (edge based). Pendekatan similarity adalah mempartisi citra menjadi daerah-daerah yang memiliki kesamaan sifat tertentu (region based) contoh: thresholding, region growing, region splitting and merging.

\subsection{Pelabelan Objek}

Bila Citra mengandung objek lebih dari satu, maka masing-masing objek dapat dihitung secara sendiri-sendiri melalui operasi pelabelan yaitu dengan cara menemukan komponen terkoneksi dalam citra karena suatu komponen terkoneksi mewakili sebuah objek. Kumpulan piksel ini dianggap sebagai objek tunggal bila tidak lagi tersambung dengan kumpulan piksel lainnya.

Algoritma untuk menemukan komponen terkoneksi dalam sebuah citra dan menandainya disebut Operasi Pelabelan Komponen. Gambar 2.15 menggambarkan sebuah citra biner dan urutan pemberian label pada objek-objeknya. 


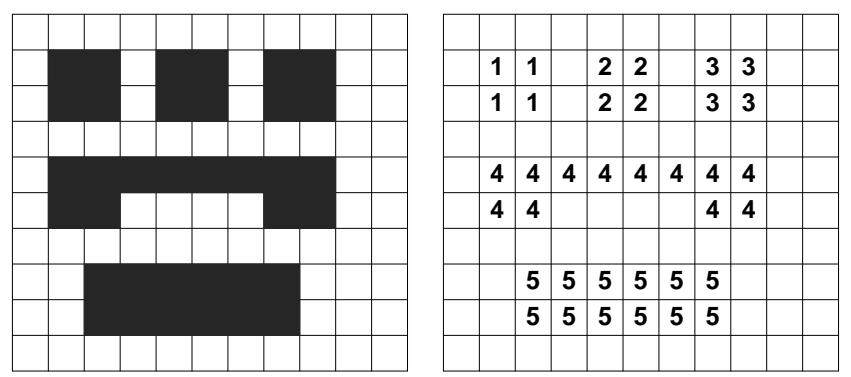

Gambar 2.15 Sebuah citra biner dan urutan pemberian label pada objek (T. Sutoyo, 2009)

Algoritma untuk pelabelan komponen dibedakan menjadi Algoritma Rekursif dan Algoritma Sekuen.

a. Algoritma Rekursif :

Algoritma rekursif lebih cocok digunakan untuk citra berukuran kecil dengan jumlah objek tidak terlalu banyak.

Langkah-langkah algoritma Rekursif :

1. Baca citra secara sistematis (misal dari kiri ke kanan, atas ke bawah) untuk menemukan piksel objek yang belum diberi label dan beri label baru.

2. Beri label yang sama pada semua piksel tetangganya.

3. Berhenti bila tidak ada lagi tetangga yang merupakan piksel objek.

4. Ulangi langkah 1 sampai 3 hingga semua piksel objek diberi label.

b. Algoritma Sekuen :

Algoritma Sekuen lebih cocok digunakan untuk citra berukuran besar dengan jumlah objek banyak.

Langkah-langkah Algoritma Sekuen :

1. Baca citra secara sistematis.

2. Jika piksel yang sedang dibaca adalah milik objek, maka :

a. Jika hanya satu dari dua piksel disebelah kiri dan atasnya yang punya label, salin labelnya.

b. Jika keduanya mempunyai label yang sama, salin labelnya.

c. Jika keduanya mempunyai label yang berbeda, salin label milik piksel di atasnya dan catat kedua label pada tabel ekivalen label.

d. Beri label baru pada piksel ini dan catat nomor label dalam tabel. 
3. Jika masih ada piksel yang perlu diperiksa, ulangi langkah 2 .

4. Temukan label terendah untuk setiap pasangan ekivalen dalam tabel.

5. Baca citra, ganti setiap label dengan label terendah dalam ekivalen tabel.

\subsection{Studi Hasil Penelitian Sebelumnya}

Sistem yang digunakan untuk membantu analisis spermatozoa telah dimulai pada tahun 1988 generasi awal tersebut dinamakan CASMA dengan menggunakan mikroskop pencahayaan fase kontras. Pada laporan yang ditulis oleh Donald T. Stephens dkk pada tahun 1988 generasi awal sperma analyzer tersebut menggunakan perekaman analog, segmentasi dan penjejakan dilakukan antar dua frame. Penjejakan spermatozoa pada frame berikutnya dengan jendela yang memperhitungkan kecepatan maksimal motilitas spermatozoa antar frame. Pemisahan spermatozoa dilakukan berdasarkan posisi masing-masing spermatozoa dan penanda yang dimiliki oleh tiap spermatozoa. Selama proses penjejakan, rekaman video ditampilkan pada layar monitor. Kepala spermatozoa yang hilang ketika penjejakan akan diberi tanda (+) di posisi terakhir, sehingga laboran dapat mengevaluasi akurasi penjejakan. Sistem ini dapat melakukan penjejakan dengan akurasi sebesar $85 \%$. Ada beberapa kelemahan pada sistem ini, yaitu:

1. Jumlah spermatozoa selama proses dibatasi sebanyak 20.

2. Tidak real time.

3. Terdapat spermatozoa yang lepas selama proses penjejakan.

Beberapa tahun kemudian diperkenalkan sebuah sistem yang disebut RSTS (Young dkk, 1996) untuk mengatasi kendala-kendala pada sperm analyzer system. RSTS (Real Time Spermatozoa Tracing System) sesuai dengan namanya, sistem ini dikembangkan dengan metode pengamatan real-time spermatozoa ketika memasuki ruang pandang mikroskop dan menjejaki lintasannya selama periode waktu tertentu. Penjejakan lintasan spermatozoa tersebut memberikan informasi hasil pengukuran berupa nilai-nilai kinematika yang dapat digunakan untuk analisa motilitas spermatozoa. Sistem ini menggunakan mikroskop pencahayaan fase kontras untuk merekam spermatozoa dengan bentuk seperti bulatan-bulatan 
bercahaya, spermatozoa tersebut disegmentasi menggunakan metode threshold grey-level. Secara berkala sistem akan melakukan scanning dalam ruang pandang mikroskop searah garis vertikal dan garis horizontal. Jika sistem menemukan spermatozoa maka sistem akan menyimpan ruang pandang seukuran $(n \times n)$ piksel yang telah ditentukan sebelumnya oleh user. Kemudian spermatozoa akan dipindahkan ke titik pusat box. Begitu seterusnya sampai spermatozoa hilang dari ruang pandang mikroskop atau sampai jumlah maksimal kotak sesuai dengan masukan user. Jumlah total frame pengamatan dapat mencapai 100-150 buah, jauh lebih banyak daripada kebanyakan sistem CASA saat itu. Sistem ini juga memiliki kelemahan diantaranya adalah :

1. Jumlah spermatozoa dalam box pengamatan berpotensi mengganggu penentuan kinematika spermatozoa.

2. Ukuran box menentukan kecepatan dan akurasi penjejakan spermatozoa.

3. Jika box yang dipergunakan besar, ada kemungkinan beberapa spermatozoa tergabung dalam satu box sehingga mempersulit perhitungan trayektori spermatozoa. Dengan kemampuan perekaman menurun hingga 12 frame/detik.

4. Jika box yang dipergunakan kecil maka ada kemungkinan spermatozoa terlepas dari proses penjejakan. 
Halaman ini sengaja dikosongkan 


\section{BAB 3 \\ METODE PENELITIAN}

Penelitian untuk mengidentifikasi abnormalitas pergerakan spermatozoa dimulai dengan desain sistem perangkat keras. Jenis mikroskop yang digunakan bright field microscope. Sistem ini menghasilkan video rekaman pergerakan spermatozoa. Video rekaman motilias spermatozoa tersebut menjadi masukan tahap penjejakan spermatozoa menggunakan mean filterbackground substraction dan mathematical morphology. Penjejakan spermatozoa menghasilkan nilai posisi 2 dimensi. Variabel RMS (root mean square) yang dibutuhkan untuk menentukan abnormalitas pergerakan spermatozoa dihitung dari posisi spermatozoa selama bergerak dalam lintasan tertentu.

\subsection{Desain Sistem}

Secara umum, desain sistem penentuan abnormalitas pergerakan spermatozoa manusia berbasis regresi linier seperti pada Gambar 3.1.

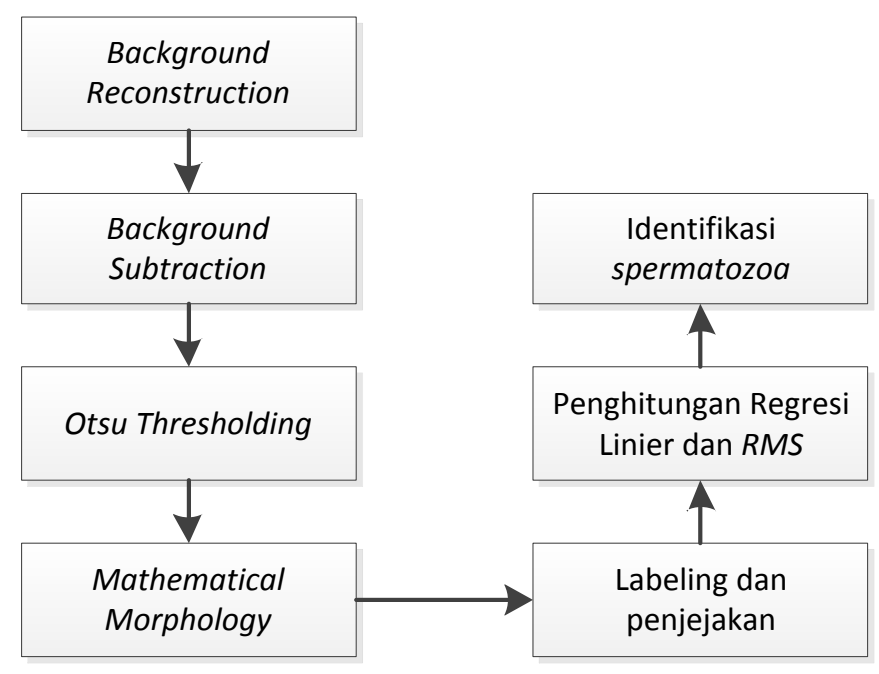

Gambar 3.1 Desain Sistem 


\subsection{Data yang digunakan}

Semua proses pengambilan video dilakukan di Laboratorium Terpadu Pendidikan dan Penelitian (DIKLIT) Politeknik Kesehatan Surabaya, Jalan Pucang Jajar Tengah 56 Surabaya.

Data yang digunakan dalam penelitian ini, berupa video sperma diperoleh dari hasil pemindaian cairan sperma relawan yang bersedia menyumbangkan cairan spermanya. Sebelum diamati, sampel tersebut didiamkan terlebih dahulu sekitar 20-30 menit dengan suhu ruang untuk kemudian diamati. Hal tersebut perlu dilakukan karena pada saat cairan sperma dikeluarkan masih kental dan perlu pengenceran supaya spermatozoa yang diamati tidak terlalu rapat, bergerak lebih aktif dan dapat jelas dibedakan.

Pengambilan video sperma menggunakan perangkat keras, terdiri dari :

1. bright field microscope

2. kamera yang digunakan merk Point Grey tipe FL3-U3-13S2C-CS yang ditempatkan sebagai pengganti lensa okuler dengan koneksi kabel USB 3.0

3. laptop merk Asus X450JF dengan prosessor Core i7, memori RAM 4 GB dan hardisk $500 \mathrm{~GB}$.

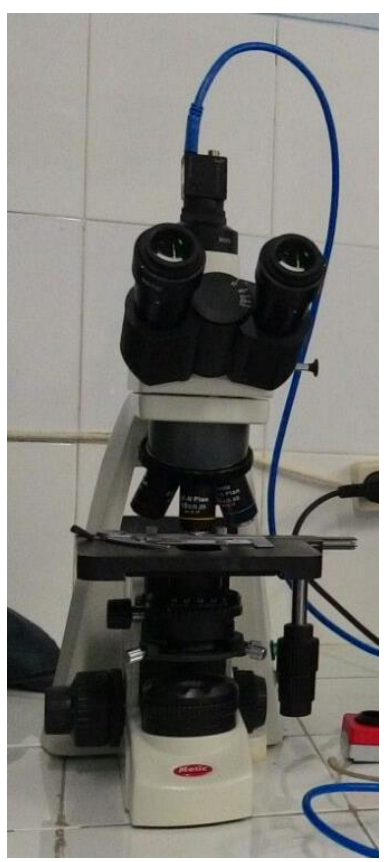

(a)

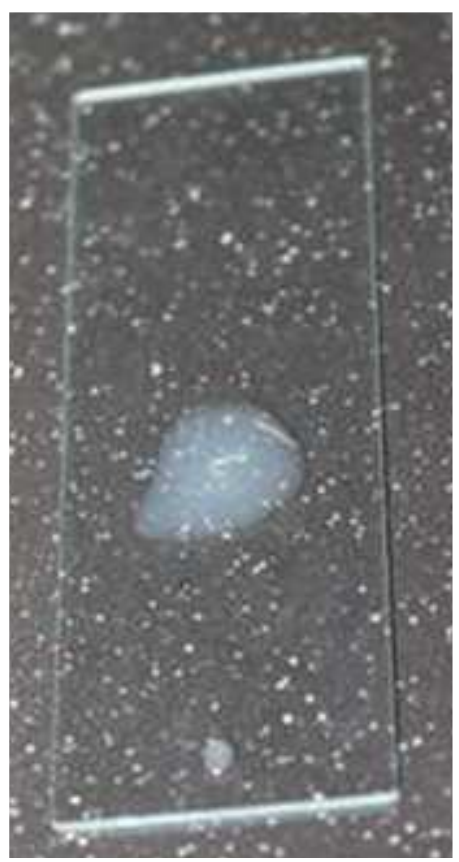

(b)

Gambar 3.3(a) Bright field microscope yang digunakan,

(b) Cairan sperma yang sudah diteteskan di atas kaca preparat 
Perekaman video dengan mikroskop diatur menggunakan lensa objektif perbesaran 40 kali sehingga motilitas spermatozoa terlihat jelas untuk diamati. Setting kamera dan program diatur supaya video mempunyai kontras, brightness dan white balance yang sama. Ruang pandang mikroskop diatur tidak bergerak selama proses perekaman. Video yang dihasilkan disimpan dan kemudian dikonversi untuk kemudian dapat diproses. Gambar 3.3(a) adalah mikroskop beserta kamera yang dimaksud, dan Gambar 3.3(b) adalah sampel cairan semen di atas preparat yang siap untuk direkam. Rekaman ini diatur untuk mendapatkan file video beresolusi 1280 x 960 piksel dengan frame rate 60 fps. Karena komputer yang digunakan kinerjanya tidak dapat menyaingi laju frame rate dari video, sehingga terkadang terjadi kelambatan hingga Sembilan frame berturut-turut. Hasilnya adalah gambar video yang tersendat-sendat dengan pergerakan objeknya pun menjadi meloncat-loncat (tidak smooth).

\subsection{Rekonstruksi Latar Belakang (Background Reconstruction)}

Untuk mengidentifikasi sperma yang bergerak, diperlukan kemampuan sistem untuk memisahkan background dan foreground yang berupa spermatozoa yang bergerak. Menggunakan background yang didapat dengan cara melakukan pemindaian ketika tidak ada sperma yang bergerak.

Penggunaan background dengan cara seperti ini menimbulkan 2 kesulitan besar, kesulitan pertama adalah proses mendapatkan background. Hal ini tentu sangat menyulitkan karena sukar sekali memperoleh kondisi dengan tidak ada sperma yang bergerak atau tidak ada sperma sama sekali, tidak mungkin dilakukan pemberhentian semua sperma untuk mendapatkan background yang diinginkan. Kesulitan kedua adalah ketidak tepatan background yang diperoleh dengan kondisi realtime saat itu. Jika background didapatkan pada satu lokasi pengamatan, kemudian background tersebut digunakan untuk mendeteksi sperma pada lokasi lain maka akan timbul permasalahan diakibatkan oleh ketidak samaan background dengan kondisi realtime saat itu diakibatkan oleh perbedaan kondisi lokasi.

Beberapa peneliti sudah melakukan penelitian tentang rekonstruksi background menggunakan serangkaian gambar bergerak. Pada (Kornprobst dkk, 
1999), dapat ditarik kesimpulan bahwa background merupakan gambar yang paling sering terlihat dari serangkaian gambar bergerak, dengan kata lain bahwa elemen pembentuk background memiliki frekuensi kemunculan yang paling sering.

Pada (Long dkk, 1990), penulis mempunyai asumsi bahwa background memiliki intensitas yang stabil pada waktu yang lama. Pada (Gloyer dkk, 1995), penulis mempunyai asumsi bahwa background setidaknya akan terlihat lebih dari $50 \%$ dari serangkaian gambar bergerak.

Dari beberapa asumsi diatas, maka dapat ditarik kesimpulan bahwa background dapat diperoleh dengan cara mengambil nilai rata-rata dari serangkaian gambar, nilai rata-rata tersebut akan mendekati gambar background yang diinginkan. Metode ini sudah umum dipakai oleh beberapa peneliti dengan menggunakan istilah TABI (time-averaged background image).

Langkah-langkah untuk mendapatkan background dengan memisahkan dari foreground berdasarkan video sperma dapat dijelaskan sebagai berikut :

Langkah ke-1: Ekstraksi Video

Video diekstrak untuk mendapatkan frame-frame dari video tersebut.

Langkah ke-2: Memperoleh frame hasil rata-rata frame video

Frame hasil ekstraksi dipilih, kemudian diambil nilai rata-rata per piksel menggunakan persamaan 1. Frame yang dipilih dapat berupa semua frame ataupun frame tertentu berdasarkan selang yang diinginkan.

\subsection{Mendapatkan Citra Biner}

Pada tahapan ini dilakukan proses segmentasi untuk membedakan atau memisahkan objek yang diamati dengan latar belakangnya (background), sebagai hasil segmentasi berupa citra biner. Sebagai masukan untuk proses ini yaitu citra dari frame-frame hasil ekstraksi video dan frame rata-rata hasil proses $T A B I$. Selanjutnya dilakukan proses mean filter yang menghasilkan nilai selisih nilai piksel yang bersesuaiankoordinatnyauntukseluruh piksel. Kemudian dilanjutkan proses thresholding dengan metode Otsu threshold, di mana nilai selisih yang 
lebih kecil dari nilai threshold, maka nilai warna diubah menjadi 0 dan jika nilai lebih besar atau sama dengan dari nilai threshold maka nilai warna dirubah menjadi 1. Dengan demikian akan didapatkan citra biner.

\subsection{Proses Filtering}

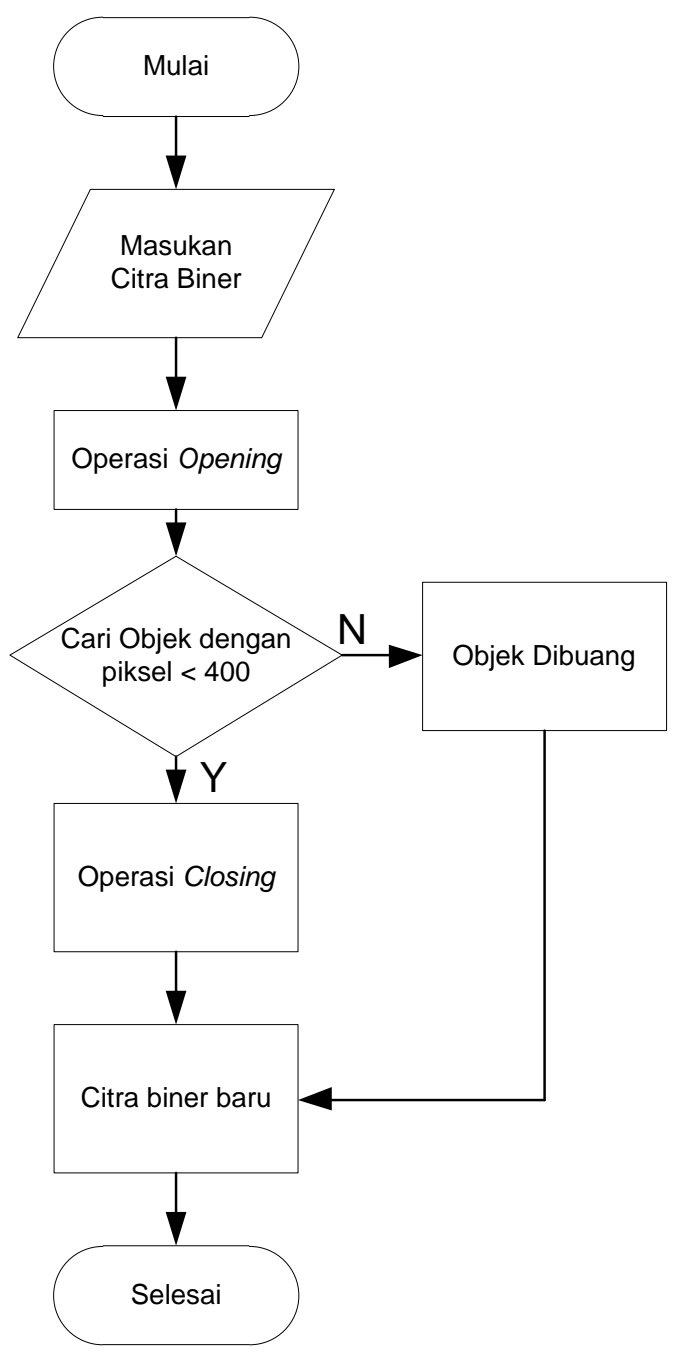

Gambar 3.5 Diagram alir proses filtering

Fitur dari citra yang telah diperoleh dari proses segmentasi biasanya masih terdapat noise, hal ini diakibatkan dari objek yang tidak diinginkan ikut tersegmentasi. Untuk menghilangan noise tersebut dilakukan proses morphological filtering seperti terlihat pada Gambar 3.5. Proses menggunakan morphological filtering pertama adalah membuang objek yang mempunyai piksel kurang dari 400 piksel. Untuk objek yang mempunyai jumlah piksel lebih dari 
400 dipertahankan. Proses yang kedua adalah membuat objek menjadi lebih halus dengan cara menutup celah-celah kecil dari objek. Proses ini menggunakan teknik operasi morfologi citra, dimana citra yang diperoleh masih perlu dihaluskan garis tepinya menggunakan teknik closing. Closing merupakan operasi morfologi yang dapat dikategorikan sebagai operasi level kedua dengan arti bahwa closing didefinisikan sebagai operasi dilasi yang dilanjutkan dengan operasi erosi, Pada operasi closing cenderung memperhalus objek pada citra dengan cara menyambung pecahan-pecahan dan menghilangkan lubang-lubang kecil pada objek.

\subsection{Labeling Objek dan Menghitung Koordinat Titik pusat Objek}

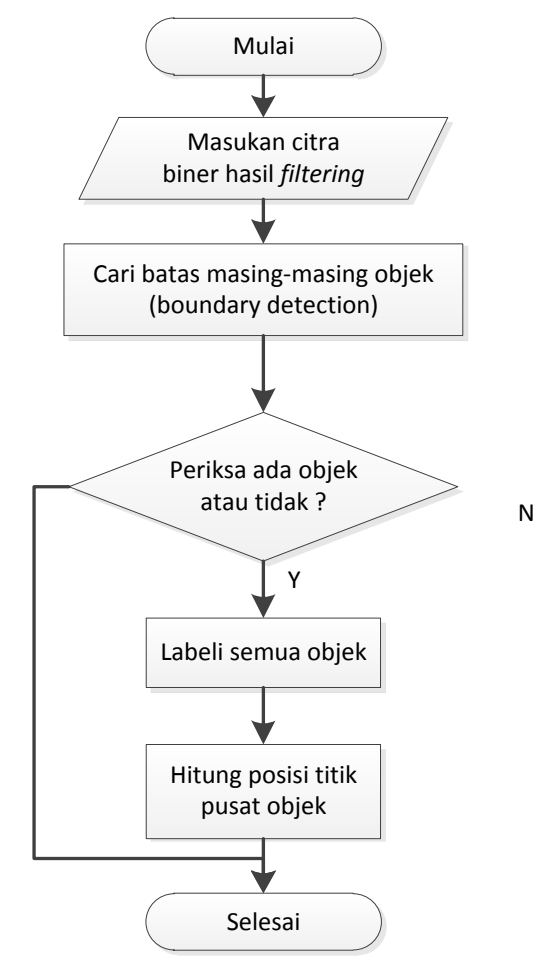

Gambar 3.6 Diagram alir untuk labeling objek dan koordinat titik pusat objek

Dari Gambar 3.6 terlihat, setelah citra diperbaiki dengan proses filtering, berikutnya citra tersebut dicari batasnya menggunakan metode deteksi bidang batas (boundary detection) untuk masing-masing objek serta dilabeli untuk setiap objek yang ditemukan. Dari masing-masing objek yang ditemukan, kemudian 
dicari koordinat titik pusat dari objek $(h, k)$ tersebut menggunakan persamaan (3.1).

$$
h=\frac{\sum_{i=1}^{n} C_{i} m_{i}}{\sum_{i=1}^{n} C_{i}} \quad k=\frac{\sum_{i=1}^{n} C_{i} o_{i}}{\sum_{i=1}^{n} C_{i}}
$$

dengan :

$$
\begin{aligned}
& C_{i} \quad=\text { luasan piksel objek } \\
& (h, k)=\text { koordinat titik pusat objek, } h \text { untuk komponen mendatar } \\
& \text { dan } k \text { untuk komponen tegak } \\
& (m, o)=\text { koordinat piksel-piksel yang ada di objek, } m \text { untuk } \\
& \text { komponen mendatar dan } o \text { untuk komponen tegak } \\
& i \quad=1,2,3, \ldots . n \\
& n \quad=\text { jumlah piksel }
\end{aligned}
$$

Pada penelitian ini luasan piksel $C_{i}$ besarnya 1 satuan, maka persamaan 3.1 menjadi :

$$
h=\frac{\sum_{i=1}^{n} m_{i}}{n} \quad k=\frac{\sum_{i=1}^{n} o_{i}}{n}
$$

\subsection{Regresi Linier Lintasan Spermatozoa}

Proses penjejakan spermatozoa selama satu sekuen pada ruang pandang yang statis akan menghasilkan nilai-nilai posisi dua dimensi penggambaran motilitasnya. Untuk dapat mengetahui bentuk gerakan dari spermatozoa, maka diperlukan suatu garis uji yang diambil dari regresi linier kumpulan koordinat posisi spermatozoa.

$$
\begin{gathered}
y=E+F x \\
E=\frac{n \sum_{i=1}^{n} h_{i} k_{i}-\sum_{i=1}^{n} h_{i} \sum_{i=1}^{n} k_{i}}{n \sum_{i=1}^{n} h_{i}^{2}-\left(\sum_{i=1}^{n} h_{i}\right)^{2}} \\
F=\frac{\sum_{i=1}^{n} k_{i} \sum_{i=1}^{n} h_{i}^{2}-\sum_{i=1}^{n} h_{i} \sum_{i=1}^{n} h_{i} k_{i}}{n \sum_{i=1}^{n} h_{i}^{2}-\left(\sum_{i=1}^{n} h_{i}\right)^{2}}
\end{gathered}
$$


Dengan $n$ adalah jumlah data, $x$ adalah sumbu $x, y$ adalah sumbu $y, E$ adalah konstanta dan $F$ adalah koefisien regresi (kemiringan dari garis regresi). Garis regresi linier $y=E+F x$ melewati kumpulan nilai posisi motilitas spermatozoa dan diukur jaraknya terhadap posisi motilitas spermatozoa selama satu sekuen.

\subsection{Root Mean Square (RMS)}

Untuk melihat apakah rata-rata posisi motilitas spermatozoa berada di garis linier maka perlu dicari nilai $R M S$, yang membandingkan nilai prediksi (garis regresi linier) dan posisi motilitas spermatozoa selama satu sekuen. Jika diberikan satu set data sebanyak $n$ yakni $\left\{X_{1}, X_{2}, \ldots, X_{n}\right\}$ maka nilai $R M S$ nya adalah

$$
R M S=\sqrt{\frac{1}{n} \sum_{i=1}^{n} r_{i}^{2}}
$$

dengan :

$$
\begin{aligned}
R M S= & \text { nilai rata-rata jarak posisi spermatozoa terhadap garis regresi } \\
& \text { linier } \\
r \quad= & \text { jarak posisi spermatozoa terhadap garis regresi linier } \\
n \quad= & \text { jumlah data }
\end{aligned}
$$

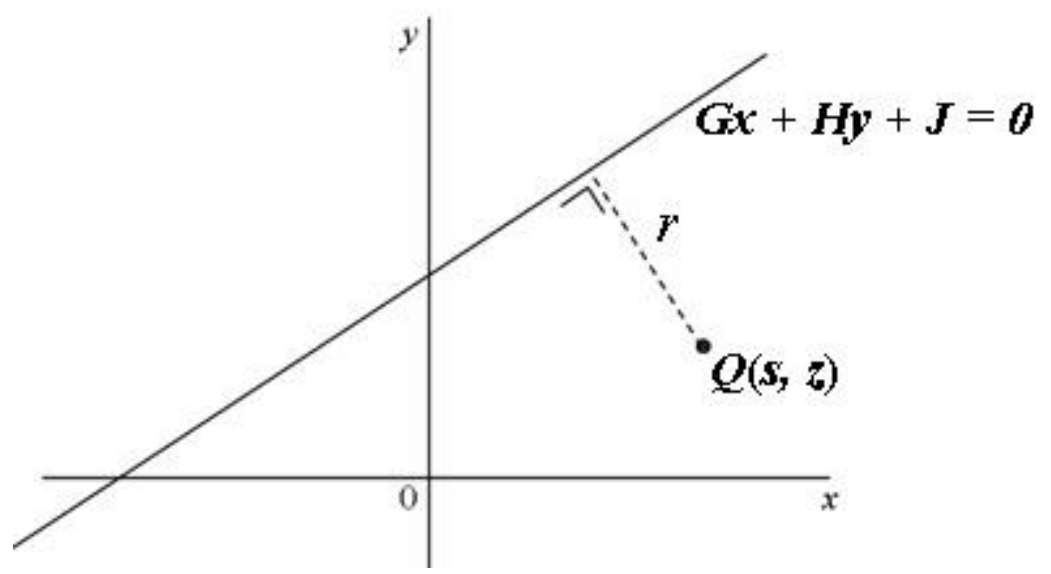

Gambar 3.7 Ilustrasi menentukan jarak titik terhadap persamaan garis

Pada Gambar 3.7, memperlihatkan ilustrasi untuk menghitung nilai $r$ yaitu jarak antara titik $Q(s, z)$ dengan sebuah persamaan garis. Untuk mendapatkan persamaan garis $G x+H y+J=0$ digunakan persamaan berikut :

$$
G x+H y+J=0
$$




$$
\begin{gathered}
G=n \sum_{i=1}^{n} h_{i} k_{i}-\sum_{i=1}^{n} h_{i} \sum_{i=1}^{n} k_{i} \\
H=\left(\sum_{i=1}^{n} h_{i}\right)^{2}-n \sum_{i=1}^{n} k_{i}^{2} \\
J=\sum_{i=1}^{n} h_{i}^{2} \sum_{i=1}^{n} k_{i}-\sum_{i=1}^{n} h_{i} \sum_{i=1}^{n} h_{i} k_{i}
\end{gathered}
$$

Untuk menghitung nilai jarak $r$ antara titik $Q(s, z)$ dengan garis $G x+H y+J=0$ digunakan persamaan berikut ini

$$
r=\frac{|G s+H z+J|}{\sqrt{G^{2}+H^{2}}}
$$


Halaman ini sengaja dikosongkan 


\section{BAB 5 \\ KESIMPULAN DAN SARAN}

Berdasarkan hasil percobaan dan analisis pada perangkat keras dan perangkat lunak yang menggunakan rekonstruksi latar belakang (background reconstruction), mean filter background substraction, peningkatan kontras Otsu threshold, operasi morfologi pada proses filtering untuk mendapatkan penjejakan objek sperma, serta penghitungan regresi linier dan nilai $R M S$, dapat diambil beberapa kesimpulan. Serta ditambahkan saran dalam pengembangan penelitian berikutnya.

\subsection{Kesimpulan}

Dengan perangkat yang dikembangkan, penentuan abnormalitas pergerakan spermatozoa manusia pada file video dapat dilakukan. Posisi pergerakan spermatozoa hasil penjejakan dikenali bentuk lintasannya berdasarkan rata-rata jarak posisinya terhadap garis regresi linier, dengan threshold 10 terdapat 4 spermatozoa progresif dan 4 spermatozoa non progresif untuk data uji, sedangkan untuk video data spermatozoa manusia terdapat 10 spermatozoa progresif dan 4 spermatozoa non progresif. Metode yang digunakan berhasil menentukan 8 (delapan) spermatozoa data UNSW Embryology, dan 14 spermatozoa manusia. Dari 8 spermatozoa data uji yang dijejaki, terdapat $50 \%$ progresif dan $50 \%$ non progresif. Sedangkan untuk 14 spermatozoa manusia yang dijejaki, terdapat $71 \%$ progresif dan $29 \%$ non progresif. Menurut WHO laboratory manual for the examination and processing of human semen tahun 2010 dengan nilai $71 \%$ progresif berarti pergerakan spermatozoa manusia normal.

\subsection{Saran}

1. Untuk penelitian berikutnya perlu adanya perangkat keras pengambilan data yang bisa menjamin kualitas video lebih baik.

2. Pada proses identifikasi dapat ditambahkan algoritma cerdas untuk mengidentifikasi objek sperma. 
Halaman ini sengaja dikosongkan 